University of Montana

ScholarWorks at University of Montana

$1-1991$

\title{
Shrimp Stocking, Salmon Collapse, and Eagle Displacement
}

Craig N. Spencer

B. Riley McClelland

Jack Arthur Stanford

The University of Montana, jack.stanford@umontana.edu

Follow this and additional works at: https://scholarworks.umt.edu/biosci_pubs

Part of the Biology Commons

Let us know how access to this document benefits you.

\section{Recommended Citation}

Spencer, Craig N.; McClelland, B. Riley; and Stanford, Jack Arthur, "Shrimp Stocking, Salmon Collapse, and Eagle Displacement" (1991). Biological Sciences Faculty Publications. 292.

https://scholarworks.umt.edu/biosci_pubs/292

This Article is brought to you for free and open access by the Biological Sciences at ScholarWorks at University of Montana. It has been accepted for inclusion in Biological Sciences Faculty Publications by an authorized administrator of ScholarWorks at University of Montana. For more information, please contact

scholarworks@mso.umt.edu. 


\title{
Shrimp Stocking, Salmon Collapse, and Eagle Displacement \\ Cascading interactions in the food web of a large aquatic ecosystem
}

\author{
Craig N. Spencer, B. Riley McClelland, and Jack A. Stanford
}

S tocking of nonnative fish and fish-food organisms has long been used by fishery managers to enhance production of freshwater fisheries. Indeed, more than $25 \%$ of the freshwater fish caught by anglers in the continental United States is from nonnative stocks (Moyle et al. 1986).

Recent studies, however, report negative effects of such introductions, especially on the native species (Moyle 1986, Schoenherr 1981, Taylor et al. 1984). For example, introduced rainbow trout (Oncorbynchus mykiss) have displaced native westslope cutthroat trout (Salmo clarki lewisi) in many Rocky Mountain streams (Allendorf and Leary 1988), and introduced brown trout (Salmo trutta) have largely replaced native brook trout (Salvelinus fontinalis) in various streams in the Midwest (Moyle et al. 1986). In the Southwest, native Gila topminnows (Poeciliopsis occidentalis) have been widely replaced by introduced mosquitofish (Gambusia affinis; Schoenherr 1981, Stanford and Ward 1986). The resulting negative, long-range, or broadscale consequences of such introduc-

Craig N. Spencer is a research assistant professor and Jack A. Stanford is director and Bierman Professor of Ecology at the Flathead Lake Biological Station, University of Montana, Polson, MT 59860. B. Riley McClelland is a research scientist at Glacier National Park, West Glacier, MT 59936 and professor in the School of Forestry, University of Montana, Missoula, MT 59812. (C) 1991 American Institute of Biological Sciences.

\section{Benefits produced by introductions have come at considerable cost}

tions have been described as the Frankenstein effect by Moyle et al. (1986). Although the most serious, or at least most widely reported, effects appear to be on native fish populations, other organisms also may be affected by introduced species.

In this article, we document particularly widespread changes cascading through the food web of the Flathead River-Lake ecosystem (Figure 1) after the introduction of the opossum shrimp (Mysis relicta). Owing to predation by the shrimp, copepod and cladoceran zooplankton populations declined dramatically, contributing to the collapse of an important planktivorous fish population. Loss of this formerly abundant forage fish caused displacement of birds and mammals that had fed on them in an upstream tributary within Glacier National Park.

\section{Shrimp introduction}

Opossum shrimp are small, 1-2centimeter-long, cold-water crustaceans that carry their young in a brood pouch, hence their name. They are native to a limited number of large, deep lakes in North America and coastal Sweden (Lasenby et al.
1986). In 1949, the shrimp were introduced experimentally into Kootenay Lake, British Columbia, with the intention of enhancing rainbow trout. However, they were largely responsible for a dramatic increase in the growth rate and size of kokanee salmon (Oncorbynchus nerka; Northcote 1972, 1973). After this initial introduction, opossum shrimp were stocked into more than 100 lakes in the northwestern United States and Canada, primarily to stimulate production of kokanee (Lasenby et al. 1986, Martinez and Bergersen 1989 , Northcote in press).

Between 1968 and 1975, opossum shrimp were introduced into three lakes in the upper portion of the Flathead catchment of northwest Montana (Figure 2) by the Montana Department of Fish, Wildlife, and Parks. The shrimp drifted downstream, and in 1981 they appeared in Flathead Lake, one of the largest natural freshwater lakes in the western United States (surface area $482 \mathrm{~km}^{2}$, mean depth $52 \mathrm{~m}$ ). Shortly thereafter, they began to alter the existing food web.

\section{Impact on zooplankton and phytoplankton}

Opossum shrimp are voracious predators of zooplankton (Figure 1); copepods are consumed, but cladocerans are preferred prey because they swim more slowly and are easier to capture (Cooper and Goldman 1980, Grossnickle 1982, Nero and Sprules 1986). After the appearance of opossum shrimp in Flathead Lake, clado- 


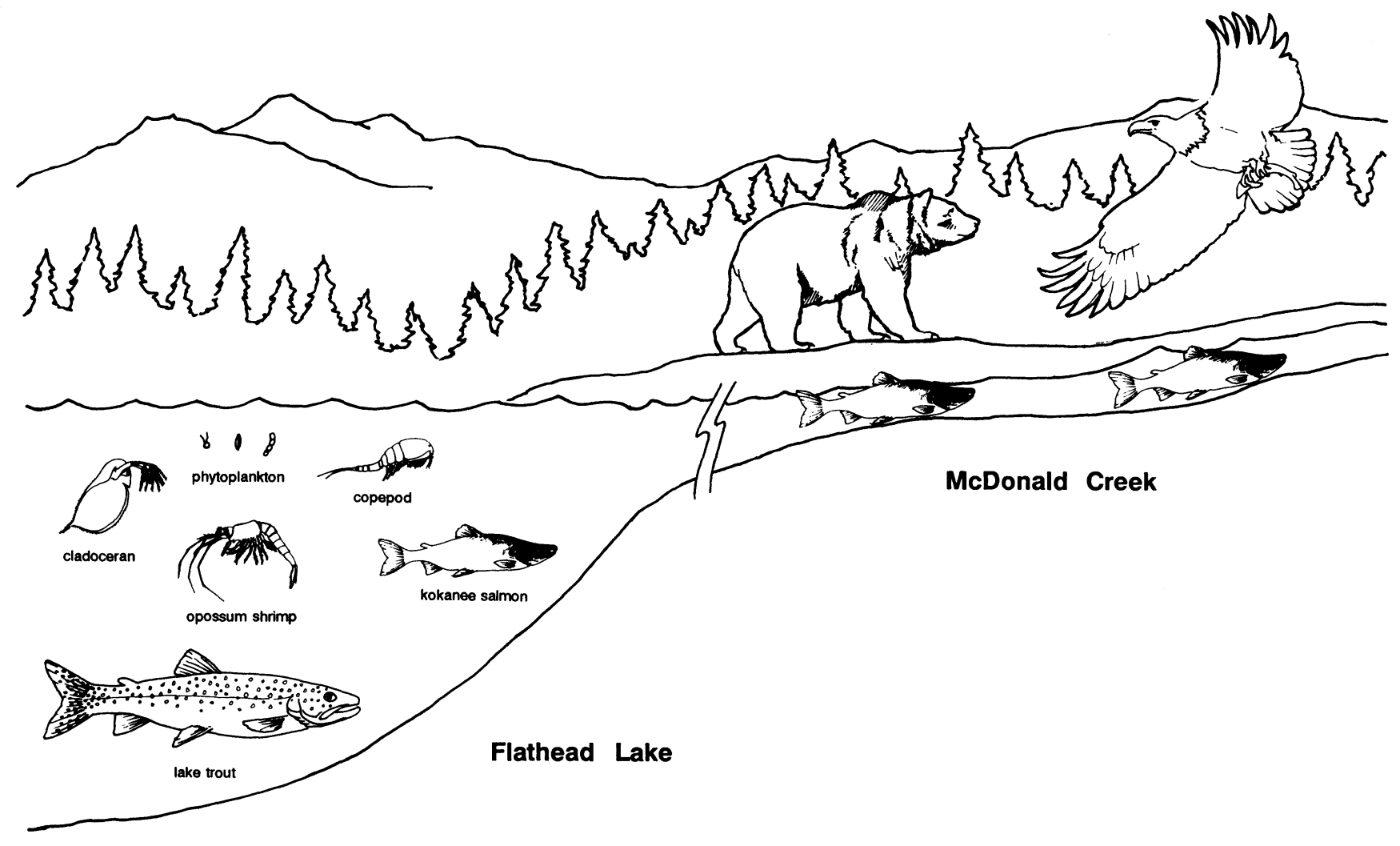

Figure 1. The food web of the Flathead River-Lake ecosystem, emphasizing those components affected by the introduction of opossum shrimp. Eagles and bears feed on spawning kokanee, lake trout eat kokanee and shrimp, kokanee and shrimp eat zooplankton (copepods and cladocerans), and zooplankton feed on phytoplankton. The organisms are not drawn to scale; they range in size from several micrometers (phytoplankton) to meters (grizzly bears).

cerans declined dramatically, with mean annual abundances reduced significantly ( $\mathrm{p}<0.0001$, Student's $\mathrm{t}$ test) from 2.8 to 0.35 organisms/ (Figure 3a, also Beattie and Clancey in press). Two of the four principal cladoceran species (Daphnia longiremis and Leptodora kindtii) disappeared from lake samples, and the other two (Daphnia thorata and Bosmina longirostris) persisted, but at greatly reduced densities. Copepods also declined significantly $(\mathrm{p}<$ 0.0001 ; Figure $3 \mathrm{~b}$ ). Although declines in cladocerans have been well documented after opossum shrimp introductions in other lakes (Morgan et al. 1978, Richards et al. 1975, Rieman and Falter 1981), similar declines in copepods have not been reported, suggesting a higher level of predation by the shrimp on zooplankton in Flathead Lake.

After peaking in 1986, opossum shrimp densities declined for three successive years (Figure 4). The zooplankton community appears to be responding to this reduction in opossum shrimp abundance. During 1988 and 1989, two cladocerans, D. longiremis and $L$. kindtii, reappeared in Flathead Lake for the first time since 1985, albeit at low densities.

Hrbacek et al. (1961), Spencer and King (1984), and Carpenter et al. (1985) have suggested that predatorinduced alterations to the herbivorous zooplankton community can cause "top-down" effects potentially regulating the abundance of phytoplankton (free-floating algae) and the appearance of algal blooms in lakes. For example, increased densities of planktivorous fish have been linked to decreased zooplankton densities and greatly increased phytoplankton abundance in nutrient-rich (eutrophic) lakes. Mean annual phytoplankton production has increased slightly since 1978 in Flathead Lake, a nutrient-poor (oligotrophic) lake (Stanford and Ellis 1988).

However, recent experiments indicate that increased phytoplankton production after the appearance of opossum shrimp is not due to declines in zooplankton grazing pressure in Flathead Lake, but rather is related to increased nutrient loading. ${ }^{1}$ Thus it appears that the phytoplankton community in Flathead Lake is regulated largely by "bottom-up" controls (nutrients), whereas top-down controls, involving changes in the upper trophic levels, may play a larger role in regulating phytoplankton production in eutrophic lakes.

\section{Impact on fish}

Although top-down effects extending to the phytoplankton are not apparent in Flathead Lake, the effects of predation by opossum shrimp on the zooplankton are widespread and have carried over to upper trophic level organisms, including the kokanee salmon. Kokanee (landlocked sockeye salmon) were introduced into Flathead Lake in 1916, and thereafter they replaced the native westslope cutthroat trout as the dominant sport fish (Tables 1 and 2).

Kokanee normally lived $3-4$ years

${ }^{1}$ C. N. Spencer, J. A. Stanford, and B. K. Ellis, 1990, unpublished data. 


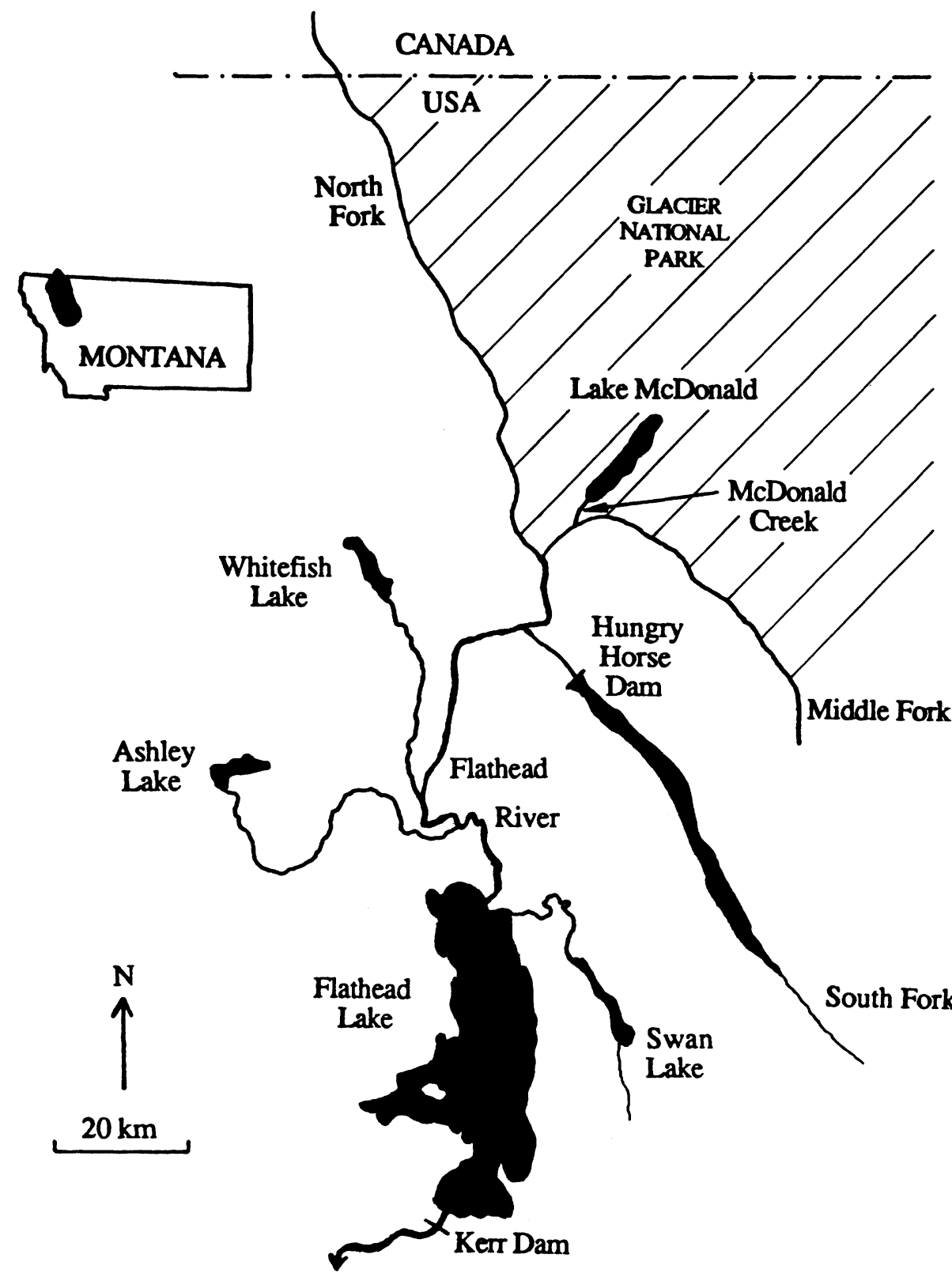

Figure 2. The Flathead River-Lake catchment $\left(22,241 \mathrm{~km}^{2}\right)$ in Montana. Location of upstream lakes where opossum shrimp were introduced in 1968 (Whitefish and Ashley lakes) and 1975 (Swan Lake) are shown. Two hydroelectric dams affect kokanee spawning grounds: Kerr Dam on Flathead Lake (completed in 1938) and Hungry Horse Dam on the south fork of the Flathead River (completed in 1952). The major kokanee spawning stream and site of bald eagle concentrations is located on McDonald Creek in Glacier National Park. We refer to the catchment shown here as the Flathead River-Lake ecosystem.

in Flathead Lake before spawning in tributary streams or along the lakeshore. The primary spawning stream was McDonald Creek in Glacier National Park, located $100 \mathrm{~km}$ upstream from Flathead Lake (Figure 2). This four-kilometer stream has favorable conditions for kokanee spawning, including loosely compacted gravel and
(Fraley et al. 1986). From 1979 to 1985 , the peak annual number of kokanee spawners varied between 26,000 and 118,000 (Figure 4). By 1985 , the density of opossum shrimp in Flathead Lake had increased to 49 organisms $/ \mathrm{m}^{2}$, illustrating the rapid growth of this invading species. Within two years, the kokanee population was noticeably reduced. In 1987 , only 330 kokanee migrated into McDonald Creek, and only 50 spawned in 1989. The salmon demise also was reflected in the annual catch by angler fishermen, which often exceeded 100,000 kokanee through 1985 (Beattie et al. 1988). As the shrimp population grew, angler harvest declined precipitously to fewer than 6000 in 1987 (Beattie et al. 1988), followed by no reported catches in 1988 and 1989.

Previous introductions of opossum shrimp into Lake Tahoe, California/ Nevada; Lake Pend Oreille, Idaho; Lake Granby, Colorado; and many other lakes produced few, if any, long-lasting benefits to the fish (primarily kokanee) that were targeted as opossum shrimp predators (Lasenby et al. 1986, Martinez and Bergerson 1989, Northcote in press). Several interactive mechanisms may explain these results.

First, opossum shrimp commonly did not become a significant component of the kokanee diet, even though they were originally introduced as a supplemental prey (Beattie et al. 1988, Bowles et al. in press, Rieman and Bowler 1980). Although both species occupy the offshore (pelagic) zone, kokanee normally are found nearer the surface in the top $30 \mathrm{~m}$ of the water column, where they concentrate their feeding activities during the day, especially around dawn and dusk (Cordone et al. 1971, Doble and Eggers 1978, Finnell and Reed 1969). Conversely, opossum shrimp spend the daylight hours on or near the bottom at depths below $30 \mathrm{~m}$, and they migrate upwards at night to feed on zooplankton (Figure 5; Beeton 1960). Because kokanee do not feed effectively on opossum shrimp at night, the vertical migration of the shrimp to deep waters during the daytime largely precludes kokanee from exploiting this new potential prey.

Enhancement of kokanee growth did occur in Kootenay Lake shortly after 

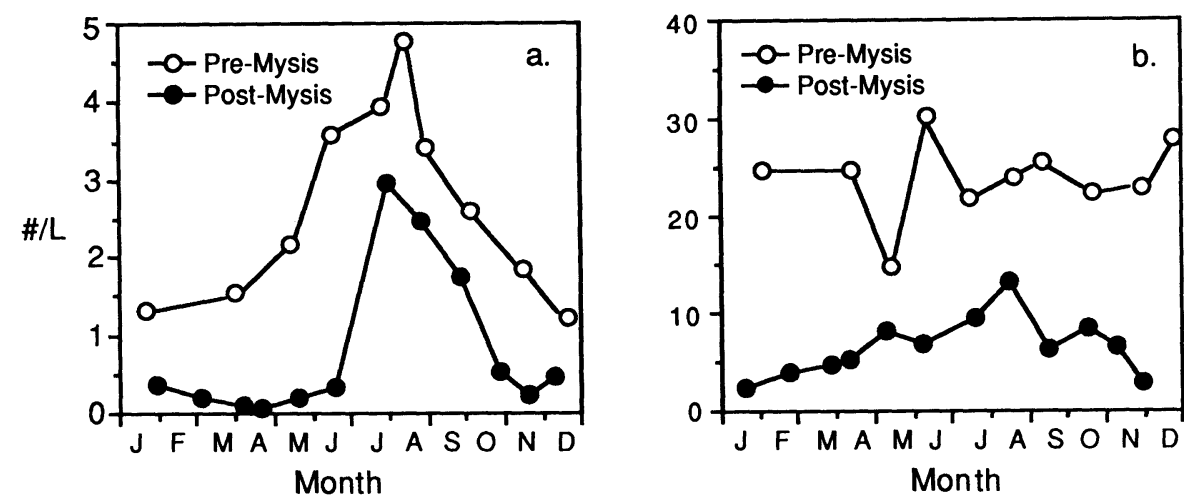

Figure 3. Seasonal abundance of cladocerans (a) and copepods (b) measured in Flathead Lake at our midlake sampling station (95 $\mathrm{m}$ deep), before the introduction of opossum shrimp (May-December 1972 and January-April 1973; from Potter 1978) and after the introduction of opossum shrimp (January-December 1988). Data are mean daytime plankton densities estimated from duplicate vertical hauls (50 m to surface) using a 64-micrometer-mesh plankton net.

the introduction of the shrimp, owing to unusual hydrologic conditions in which upwelling currents carried the

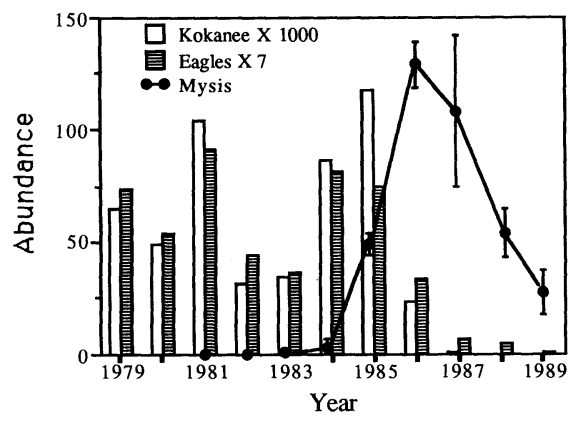

Figure 4. Shrimp, salmon, and eagle abundance. Mean annual autumn lakewide abundance of opossum shrimp (Mysis; number $/ \mathrm{m}^{2}$ ) in Flathead Lake estimated from vertical net hauls (bottom to surface) collected at $25-40$ randomly chosen locations throughout the lake. Collections were made on moonless nights using a 1-meter-diameter, 500-micron-mesh plankton net. Opossum shrimp data from 1981 to 1986 are from Bukantis and Bukantis (1987). The error bars represent $95 \%$ confidence intervals for each lakewide estimate. (Error bars 1984-1986 are from R. Bukantis, 1990, personal communication. Montana Water Quality Bureau, Helena, MT.) Eagle and kokanee abundance data are annual peaks of weekly (eagles) and biweekly (kokanee) counts made along the entire 4-kilometer reach of McDonald Creek. These data are absolute counts of the total local population, and thus no error estimation is possible. To obtain specific eagle and kokanee densities from the figure, the values shown must be multiplied by 7 and 1000 , respectively. shrimp from the central region of this deep lake into a shallow bay, where they lacked a deepwater daytime refuge (Northcote 1972). However, after two decades of increased kokanee production in Kootenay Lake, the kokanee declined significantly in the 1970 s, reportedly due to complex changes in the lake including decreased nutrient loading and construction of a large upstream dam, which altered hydrologic flows and trapped nutrients (Northcote in press).

A second explanation for the common failure of opossum shrimp to stimulate kokanee production is interspecific competition for food resources. Like opossum shrimp, kokanee are planktivores throughout their existence in the lake environment (Cooper and Goldman 1980, Leathe and Graham 1982, Rieman and Falter 1981, Vinyard et al. 1982). Thus previous kokanee declines that followed introduction of opossum shrimp have been largely attributed to interspecific competition for a severely depleted supply of cladocerans (Lasenby et al. 1986, Northcote in press). Competition for scarce food resources is not restricted just to juvenile kokanee and opossum shrimp. Adult kokanee also feed primarily on cladocerans, probably explaining the dramatic decline in kokanee spawners from Flathead Lake in 1987, just two years after the initial large increase in opossum shrimp abundance (Figure 4).

Although the prevailing evidence strongly suggests that the recent col- lapse of the kokanee spawning run in McDonald Creek is linked to the appearance of opossum shrimp in Flathead Lake, the situation is complicated by past kokanee declines in other areas of the Flathead ecosystem. These declines may be partially attributed to water-level fluctuations caused by hydroelectric dams on both the south fork of the Flathead River and on Flathead Lake (Figure 2). Changing water levels resulting from operation of these dams reportedly caused kokanee spawning areas in both the river and along the lakeshore to become dessicated, killing kokanee eggs (Fraley et al. 1986, 1989, Fraley and Decker-Hess 1987). The kokanee also may have been stressed by intensive annual harvests by anglers, which often removed $50 \%$ or more of the adult kokanee population (Beattie et al. 1988).

Although the kokanee were likely affected by these long-term stresses (the dams were constructed more than 35 years ago), a sustained kokanee population and fishery existed in Flathead Lake through the mid1980s, with adult kokanee populations of several hundred thousand fish, and natural kokanee recruitment of 9 million or more fry per year coming largely from undisturbed McDonald Creek in recent years (Beattie et al. 1988, Clancey and Fraley 1986). Then, in just a few years after the establishment of opossum shrimp, the kokanee collapsed almost completely.

Comparable declines have been documented elsewhere, in which fish pop-

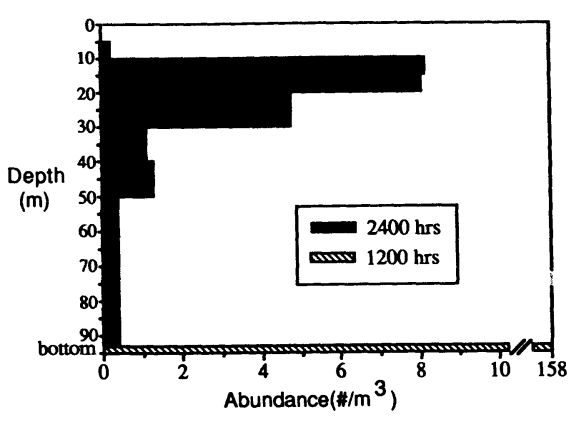

Figure 5. Vertical distribution of opossum shrimp measured on 16 August 1988 at our midlake sampling station in Flathead Lake at midday and midnight. Collections were made using vertical hauls with a closing net (1-meter-diameter, 500micrometer mesh). Note all opossum shrimp at midday were found at the bottom of the lake. 


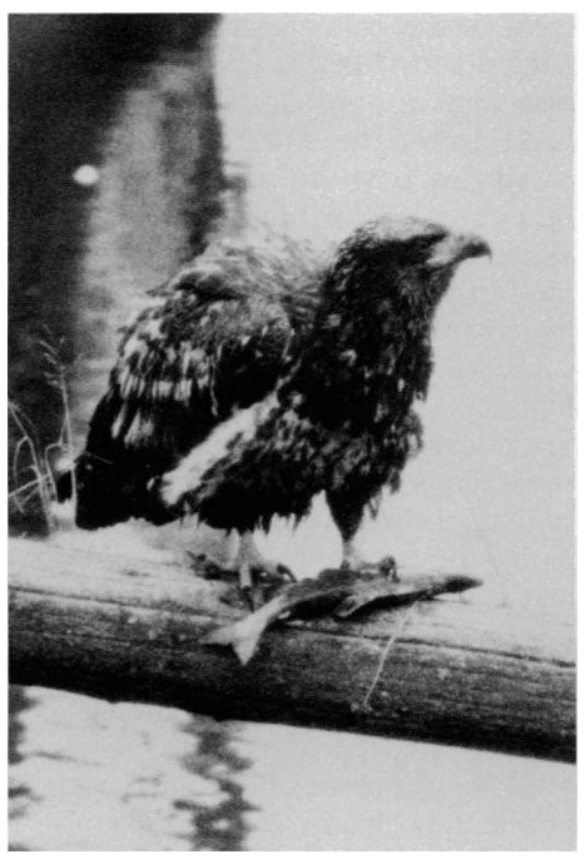

Figure 6. An immature bald eagle with a kokanee salmon taken from McDonald Creek in Glacier National Park. Photo: B. Riley McClelland.

ulations, already under stress, have been rapidly eliminated after invasions of nonnative species. For example, the classic case history of Lake Michigan includes a productive lake trout (Salvelinus namaycush) fishery, which persisted in the 1930s and early 1940s in spite of overexploitation by commercial fishermen and apparently degraded habitat. After the invasion of the exotic sea lamprey (Petromyzon marinus), the lake trout population collapsed almost completely during a period of just 4-5 years, as sea lampreys preyed on the already-stressed lake trout population (Christie 1974, Wells and McLain 1972).

\section{Impact on birds and mammals}

Collapse of the kokanee population has affected other components of the food web, including the wildlife on tributaries of Flathead Lake. The most intensely studied location, McDonald Creek (Figures 1 and 2), attracted each autumn a spectacular diversity and abundance of birds and mammals, which fed on spawning kokanee, their carcasses, and kokanee eggs.

Bald eagles were the most prominent of the predators and scavengers, gathering by the hundreds during their au- tumn migration along $\mathrm{McDonald}$ Creek (Figure 6). The first record of a bald eagle concentration in this area is from 1939, when 37 eagles were reported; kokanee had been first observed in 1935 (McClelland 1973).

Systematic counts of eagles along McDonald Creek were conducted by canoe once each week during autumn beginning in 1965 (McClelland et al. 1982). Peak numbers of eagles were strongly correlated with peak numbers of kokanee spawners (Figure 7; McClelland and McClelland 1986). In 1981 , for example, more than 100,000 kokanee spawners and 639 bald eagles were tallied during a single count. For many years, the autumn congregation of bald eagles on McDonald Creek (Figure 8) was the densest concentration of the species south of Canada. Then, beginning in 1987, numbers of eagles declined precipitously concomitant with the demise of the kokanee food resource, reaching a low of 25 eagles counted in 1989 (Figure 4).

Migration routes of eagles along McDonald Creek have been studied since 1977; orange wing markers were placed on 121 eagles and 66 were equipped with radio transmitters. Tracking of transmitter-equipped eagles before the kokanee collapse showed that nearly all the eagles migrated to McDonald Creek from summering areas in northwestern Canada. After salmon numbers were depleted each autumn, the eagles continued south to wintering areas elsewhere in the western United States (Young 1983, Young et al. 1983).

Recent increases in the number of reported eagles at two reservoirs in western Montana, where introduced kokanee populations have expanded, led to speculation by the local press that the McDonald Creek eagles rapidly shifted to these new food sources. In 1989, more than 200 bald eagles were counted near Hauser Reservoir, $270 \mathrm{~km}$ southeast of Glacier Park, ${ }^{2}$ and more than 100 were seen near Koocanusa Reservoir, $100 \mathrm{~km}$ west of the park. ${ }^{3}$

Although these sightings followed the decline at McDonald Creek, we do not believe these events are apprecia-

${ }^{2}$ A. Harmata, 1989, personal communication. Montana State University, Bozeman.

${ }^{3} \mathrm{M}$. Swanson, 1989 , personal communication. U.S. Forest Service volunteer. bly related. Both of the newer locations supported eagle concentrations before the kokanee collapse in Flathead Lake. Intensive observations near Koocanusa Reservoir from 1983 to 1989 (186 eagles were recorded in a single count in 1988) documented no more than one marked eagle from McDonald Creek in any one year either before or after the collapse. ${ }^{4}$ No marked eagles have been reported at Hauser Reservoir. Furthermore, ongoing studies 5 indicate that at least several hundred eagles still pass through the McDonald Creek area during migration, quickly moving southward toward wintering areas, not toward the Koocanusa or Hauser reservoirs.

The collapse of the McDonald Creek spawning run clearly represents the loss of a valuable food resource for the bald eagle, an endangered or threatened species in the contiguous United States. Although kokanee salmon are not native to Flathead Lake or McDonald Creek, migrating bald eagles took advantage of this abundant food resource for more than 50 years, when many of their historical prey species were no longer common.

The eagles cannot respond to the loss of Flathead Lake kokanee by simply returning to native prey elsewhere. The once-abundant carrion of bison (Bison bison) and elk (Cervis elaphus) on the plains east of Glacier National Park, and the anadromous salmon in headwaters of the Columbia River to the west, are now much reduced or absent (Netboy 1980, Schmidt and Gilbert 1978, Schultz 1919). Therefore, loss of the kokanee spawning run could lead to higher eagle mortality during migration or during winter, especially among juvenile eagles (McClelland et al. 1983, Newton 1979, Stalmaster and Gessaman 1984), if adequate alternate food resources are not available.

Other wildlife species that were attracted to the spawning run in McDonald Creek also have been affected by the kokanee collapse. Herring gull (Larus argentatus), California gull (Larus californicus), common merganser (Mergus merganser), and mallard (Anas platyrhynchos) fed on kokanee, whereas other bird species,

${ }^{4}$ See footnote 3 .

${ }^{5}$ B. R. McClelland, 1990, manuscript in preparation. 


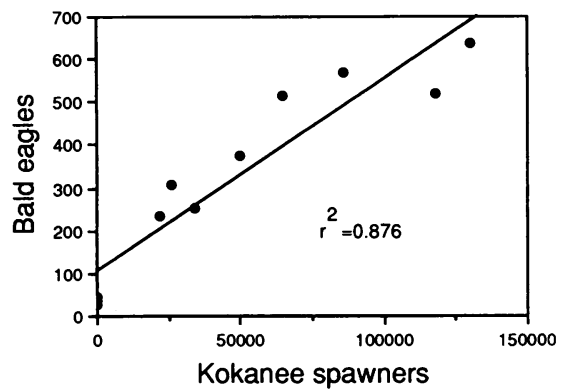

Figure 7. Relationship between peak numbers of kokanee spawners and bald eagles along McDonald Creek, 1979-1989. The relationship is significant at the $\mathrm{p}=$ 0.0001 level.

including common goldeneye (Bucephala clangula), Barrow's goldeneye (Bucephala islandica), and American dipper (Cinclus mexicanus), fed on kokanee eggs.

Coyotes (Canis latrans), mink (Mustela vison), river otter (Lutra canadensis), and even white-tailed deer (Odocoileus virginianus; Shea 1973), also made use of the abundant kokanee food resource. Grizzly bears (Ursus arctos) trapped spawning kokanee in shallow riffles and dove to the bottom of five-meter-deep pools to recover dead salmon from the creek bottom. One individual bear, distinctive because of the absence of one ear, was observed for 11 consecutive autumns. During years of abundant, late-season kokanee spawning runs, several grizzlies were active much later than the usual onset of hibernation. Since the kokanee collapse, bears and most other kokanee feeders have been far less common along McDonald Creek in the autumn.

Finally, collapse of the kokanee spawning run has diminished the number of human visitors to Glacier National Park in autumn. At a designated viewing area on McDonald Creek, park visitors often could see more than 100 eagles at one time. Since the collapse, visits to the viewing area have declined from a maximum of 46,500 in 1983 to fewer than 1000 in 1989.

\section{The future}

We expect that the Flathead Lake food web will shift from pelagic kokanee toward benthic-feeding fish species, which can exploit the abundant daytime opossum shrimp concentrations on the lake bottom (Fig- ure 5). Already, it appears that two such species, lake whitefish (Coregonus clupeaformis) and small-sized lake trout, have become more abundant in Flathead Lake, as has been reported in other lakes after the introduction of opossum shrimp (Morgan et al. 1978, Wydoski and Bennett 1981). We suspect that enhanced survival and growth of young lake trout, as a result of the opossum shrimp introduction, may have contributed to the kokanee decline, because lake trout prey heavily on kokanee.

Although the mean size of lake trout appears to have declined after the introduction of opossum shrimp, the smaller lake trout are more desirable to some anglers. When the larger lake trout fed on kokanee, they had an oily taste. Many of the smaller lake trout caught recently seem less oily, presumably due in part to their consumption of opossum shrimp. However, trophy lake trout $(10-20 \mathrm{~kg})$ currently appear to be less abundant than in years when kokanee were abundant. We do not know the impact of opossum shrimp on important native sportfish in Flathead Lake, including bull trout (Salvelinus confluentus) and westslope cutthroat trout.

After peaking in 1986, opossum shrimp densities have declined for three successive years (Figure 4), apparently due to predation from the newly expanding fish populations, as well as reduced prey availability (Figure 3). Several cladoceran species have reappeared in the last two years, presumably in response to the reduced abundance of opossum shrimp.

We expect that opossum shrimp and zooplankton populations will continue to exhibit cyclic oscillations characteristic of some predator-prey interactions. If predation on opossum shrimp by other fish species continues to intensify, further reducing the densities of this kokanee competitor, then kokanee populations may respond to a limited extent. Such trends have not been observed elsewhere, however.

It is likely that many bald eagles gradually will shift their southward migration route away from the immediate area of McDonald Creek in search of alternate prey. However, because McDonald Creek is within a well-established raptor migration corridor, we expect that some eagles will continue to use this route.

Although the Flathead ecosystem, which includes much of Glacier $\mathrm{Na}$ tional Park, is considered relatively pristine and largely undisturbed (supporting a natural assemblage of only 10 native fish species), it has been perturbed over the years through introductions of at least 17 nonnative fish (Table 2), crayfish (Orchonectes virilis), and most recently opossum shrimp.

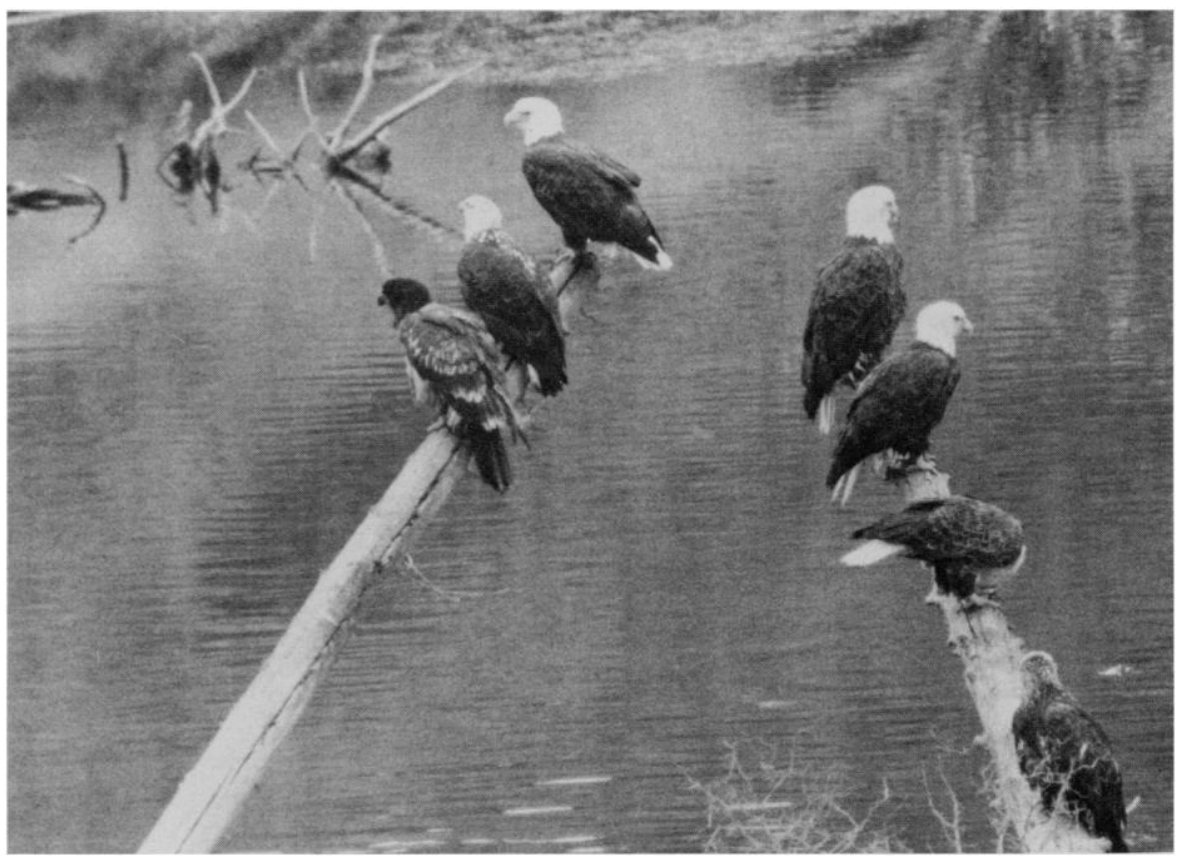

Figure 8. In some years, more than 500 bald eagles congregated along the fourkilometer stretch of McDonald Creek. Photo: B. Riley McClelland. 
Table 1. Native fish species within the Flathead River-Lake ecosystem.

Common name (Latin name)

Bull trout (Salvelinus confluentus)

Westslope cutthroat trout (Oncorhynchus clarki lewisi)

Mountain whitefish (Prosopium williamsoni)

Pygmy whitefish (Prosopium coulteri)

Peamouth (Mylocheilus caurinus)

Northern squawfish (Ptychocheilus oregonensis)

Longnose sucker (Catostomus catostomus)

Largescale sucker (Catostomus macrocheilus)

Redside shiner (Richardsonius balteatus)

Slimy sculpin (Cottus cognatus)

The practice of stocking nonnative species, in Flathead Lake and around the world, has been a cornerstone of fisheries management for many years. Some introductions have resulted in popular sport fisheries, whereas others have produced inadvertent benefits, such as the opportunity for bald eagles to prey on introduced kokanee in Glacier National Park.

Nevertheless, many of the perceived benefits of nonnative introductions are short-lived due to instabilities in disturbed food webs, such as the loss of bald eagle/kokanee congregations in Glacier National Park and the eventual decline in the kokanee fishery in Kootenay Lake. More important, the benefits produced by introductions have come at considerable costs, including loss or reduction of many native species, a public largely uninformed about the value of nongame species and natural biodiversity because the management agencies have typically stressed only the benefits of the new species, and numerous management problems created by unstable fish populations and food webs (Moyle et al. 1986).

In recent years, many agencies have adopted more conservative policies regarding introduction of nonnative species; nevertheless, introductions continue at an alarming rate. Some are intentional (via agency efforts or illegal fish plantings by private citizens), and some occur via accidental means, including downstream drift or even accidental transport on boats, as evidenced by the recent discovery in the Laurentian Great Lakes of nuisance zebra mussels (Dreissena polymorpha) and a predatory cladoceran (Bythetrephes cederstroemi) apparently released in ballast water from ships traveling from Eurasia (Lange and Cap 1986, Roberts 1990). We encourage stricter controls aimed at preventing further introductions, particularly until we can predict cascading effects within food webs of aquatic ecosystems.

\section{Acknowledgments}

We thank P. T. McClelland and D. S. Shea for their work on eagle research in Glacier National Park for more

Table 2. Nonnative fish species introduced within the Flathead River-Lake ecosystem.

\begin{tabular}{lcc}
\hline Nonnative species & $\begin{array}{c}\text { Year first } \\
\text { introduced }\end{array}$ & $\begin{array}{c}\text { Current range in } \\
\text { the ecosystem }\end{array}$ \\
\hline Largemouth bass (Micropterus salmoides) & $1898^{\dagger}$ & $\begin{array}{l}\text { Limited } \\
\text { Lake trout (Salvelinus namaycush) }\end{array}$ \\
Lake whitefish (Coregonus clupeaformis) & 1905 & Extensive \\
Pumpkinseed (Lepomis gibbosus) & 1909 & Extensive \\
White crappie (Pomoxis annularis) & 1910 & Moderate \\
Smallmouth bass (Micropterus dolomieui) & 1910 & Limited \\
Black bullhead (Ictalurus melas) & 1910 & Limited \\
Yellow perch (Perca flavescens) & 1910 & Limited \\
Brook trout (Salvelinus fontinalis) & $1913^{\dagger}$ & Moderate \\
Yellowstone cutthroat trout (Salmo clarki bouvieri) & $1913^{\dagger}$ & Limited \\
Arctic grayling (Thymallus arcticus) & 1913 & Limited \\
Rainbow trout (Oncorhynchus mykiss) & $1914^{\dagger}$ & Limited \\
Kokanee salmon (Oncorhynchus nerka) & $1916^{\dagger}$ & Moderate \\
Chinook salmon (Oncorhynchus tschawytscha) & 1916 & Moderate \\
Golden trout (Oncorhynchus aguabonita) & $1938^{\ddagger}$ & Absent \\
Northern pike (Esox lucius) & $1965^{\lessgtr}$ & Limited \\
Coho salmon (Oncorbynchus kisutch) & 1969 & Limited \\
\hline
\end{tabular}

*Modified from Hanzel 1969.

tSpecies introduced on multiple occasions after the initial introduction.

${ }^{\ddagger} \mathrm{B}$. Cheff, 1988, personal communication, Charlo, MT.

SUnauthorized introduction of pike was apparently carried out by private citizens. The date of thi $\rightarrow$ first introduction is unknown; the first recorded observation of pike in the ecosystem was in 1965 (Hanzel 1976). than two decades; H. L. Allen, R. E. Bennetts, E. M. Caton, J. G. Crenshaw, D. E. Lange, M. E. McFadzen, E. B. Spettigue, R. M. Williams, R. E. Yates, and L. S. Young for assistance in various phases of Glacier Park eagle research; R. T. Bukantis for opossum shrimp data from 1981 to 1986 and discussions regarding zooplankton analysis; D. S. Potter for preopossum shrimp zooplankton data; the Montana Department of Fish, Wildlife, and Parks for cooperation and use of kokanee data (however, interpretations of these data are the authors'); R. Petty for Figure 1; J. Craft, J. B. Imbert, R. Steinkraus, and J. Tohtz for assistance with opossum shrimp and zooplankton sampling and counting; B. K. Ellis for help with sampling on Flathead Lake and primary production data; and M. Spencer, K. Fausch, A. Covich, W. Beattie, J. Fraley, R. Hutto, and C. Hall for helpful comments on the manuscript. Funding for Flathead Lake research provided by Jessie Bierman, Lakeside, MT; the Flathead Basin Commission, Kalispell, MT; and the Montana Department of Fish, Wildlife, and Parks. Bald eagle research was funded by the USDI National Park Service, Montana Forest and Conservation Experiment Station, Wildlife Management Institute, National Audubon Society, Alberta Fish and Wildlife Division, Parks Canada, Canadian Department of Indian and Northern Affairs (Geology Division), Northwest Territories Wildlife Service, Canadian Wildlife Service, and Echo Bay Mines.

\section{References cited}

Allendorf, F. R., and R. Leary. 1988. Conservation and distribution of genetic variation in a polytypic species, the cutthroat trout. Conserv. Biol. 2: 170-184.

Beattie, W. P., and P. Clancey. In press. Effects of the establishment of opossum shrimp (Mysis relicta) on the zooplankton community, and coincident decline in the survival of kokanee (Oncorbynchus nerka) in Flathead Lake, Montana. Am. Fish. Soc. special publication.

Beattie, W., P. Clancey, and R. Zubik. 1988. Effect of the operation of Kerr and Hungry Horse dams on the reproduction success of kokanee in the Flathead system. Project no. 81-S-5. Report to the Bonneville Power Administration, Portland, OR. Montana Department of Fish, Wildlife, and Parks, Kalispell, MT.

Beeton, A. M. 1960. The vertical migration of Mysis relicta in Lakes Huron and Michigan. J. Fish. Res. Bd. Can. 17: 517-539. 
Bowles, E. C., B. E. Rieman, G. R. Mauser, and D. H. Bennett. In press. Effects of mysid introductions on fishery resources in north ern Idaho. Am. Fish. Soc. special publication.

Bukantis, R. T., and J. G. Bukantis. 1987. Mandibles. Montana Outdoors 18: 15-17, 26.

Carpenter, S. R., J. F. Kitchell, and J. R. Hodgson. 1985. Cascading trophic interactions and lake productivity. BioScience 35 : 634-639.

$\rightarrow$ Christie, W. J. 1974. Changes in fish specie composition of the Great Lakes. J. Fish. Res. Bd. Can. 31: 827-854.

Clancey, P., and J. Fraley. 1986. Effects of the operation of Kerr and Hungry Horse Dams on the kokanee fishery in the Flathead River system. Project No. 81-S-5. Report to the Bonneville Power Administration, Portland, OR. Montana Department of Fish, Wildlife, and Parks, Kalispell, MT.

$\rightarrow$ Cooper, S. D., and C. R. Goldman. 1980. Opossum shrimp (Mysis relicta) predation on zooplankton. Can. J. Fish. Aquat. Sci. 37: 909-919.

Cordone, A. J., S. J. Nicola, P. H. Baker, and T. C. Frantz. 1971. The kokanee salmon in Lake Tahoe. California Fish and Game 57: $28-43$.

$\rightarrow$ Doble, B. D., and D. M. Eggers. 1978. Diel feeding chronology, rate of gastric evacuation, daily ration, and prey selectivity in Lake Washington juvenile sockeye salmon (Oncorhynchus nerka). Trans. Am. Fish. Soc. 107 $26-45$.

$\rightarrow$ Finnell, L. M., and E. B. Reed. 1969. The diel vertical movements of kokanee salmon, Oncorbynchus nerka, in Granby Reservoir, Colorado. Trans. Am. Fish. Soc. 98: 245-252.

$\rightarrow$ Fraley, J., and J. Decker-Hess. 1987. Effects of stream and lake regulation on reproductive success of kokanee in the Flathead River system, Montana, U.S.A. Regul. Rivers Res. o Manage. 1: 257-265.

$\rightarrow$ Fraley, J., B. Marotz, J. Decker-Hess, W. Beattie, and R. Zubik. 1989. Mitigation, compensation, and future protection for fish populations affected by hydropower development in the Upper Columbia system, Montana, U.S.A. Regul. Rivers Res. \& Man age. 3: 3-18.

$\rightarrow$ Fraley, J. J., S. L. McMullin, and P. J. Graham. 1986. Effects of hydroelectric operations on the kokanee populations in the Flathead River system, Montana. N. Am. J. Fish. Manage. 6: 560-568.

$\rightarrow$ Grossnickle, N. E. 1982. Feedings habits of Mysis relicta-an overview. Hydrobiologia 93: 101-107.

Hanzel, D. A. 1969. Flathead Lake, investigation of its fish populations and its chemical and physical characteristics. Project F-33R-3, job no. I, final report. Montana Department of Fish and Game, Kalispell, MT.

1976. History of northern pike in the Flathead River. Montana Department of Fish and Game, Kalispell, MT.

Hrbacek, J., M. Dvorakova, V. Korinek, and L. Prochazkova. 1961. Demonstration of the effect of fish stock on the species composition of zooplankton and the intensity of metabolism of the whole plankton assemblage. Int. Ver. Theor. Angew. Limnol. Verh. 14: 192-195.

$\rightarrow$ Lange, C., and R. Cap. 1986. Bythetrephes cederstroemi, (Schodleri). (Cercopagidae:
Cladocera): a new record for Lake Ontario. J. Gt. Lakes Res. 12: 142-143.

Lasenby, D. C., T. G. Northcote, and M. Furst. 1986. Theory, practice, and effects of Mysis relicta introductions to North American and Scandinavian lakes. Can. J. Fish. Aquat. Sci. 43: 1277-1284.

Leathe, S. A., and P. J. Graham. 1982. Flathead Lake Fish Food Habits Study. Final report to EPA, Denver, CO. Montana Department o Fish, Wildlife, and Parks, Kalispell, MT

Martinez, P. J., and E. P. Bergersen. 1989. Proposed biological management of Mysis relicta in Colorado lakes and reservoirs. $N$. Am. J. Fish. Manage. 9: 1-11.

McClelland, B.R. 1973. Autumn concentration of bald eagles in Glacier National Park. Condor 75: 121-123.

McClelland, B. R., and P. T. McClelland. 1986. Bald eagles and kokanee salmon: rendezvous in Glacier National Park. West. Wildlands 11: 7-11.

McClelland, B. R., L. S. Young, D. S. Shea, P. T. McClelland, H. L. Allen, and E. B. Spettigue. 1982. The bald eagle concentration in Glacier National Park: origin, growth, and variation it numbers. Living Bird 19: 133-155.

1983. The bald eagle concentration ir -

Glacier National Park, Montana: an international perspective for management. Pages 69-77 in D. M. Bird, ed. Biology and Management of Bald Eagles and Ospreys. Harpell Press, Quebec.

Morgan, M. D., S. T. Threlkeld, and C. R. Goldman. 1978. Impact of the introduction of kokanee (Oncorbynchus nerka) and opossum shrimp (Mysis relicta) on a subalpine lake. J. Fish. Res. Bd. Can. 35: 1572-1579.

Moyle, P. B. 1986. Fish introductions into North America: patterns and ecological impact. In H. Mooney and J. A. Drake, eds. Biological Invasions in North America. Springer-Verlag, New York.

Moyle, P. B., H. W. Li, and B. A. Barton. 1986. The Frankenstein effect: impact of introduced fishes on native fishes in North America. Pages 415-426 in R. H. Stroud, ed. Fish Culture in Fisheries Management. American Fisheries Society, Bethesda, MD.

Nero, R. W., and W. G. Sprules. 1986. Predation by three glacial opportunists on natural zooplankton communities. Can. J. Zool. 64 57-64.

Netboy, A. 1980. The Columbia River Salmon and Steelhead Trout: Their Fight for Survival. University of Washington Press, Seattle.

Newton, I. 1979. Population Ecology of Raptors. Buteo Books, Vermillion, SD.

Northcote, T. G. 1972. Some effects of mysid introduction and nutrient enrichment on ar $\rightarrow$ oligotrophic lake and its salmonids. Verhandlung Internationale Vereinege Limnologie 18: 1096-1106.

1973. Some impacts of man on Kootenay Lake and its salmonids. Great Lakes Fisheries Committee Technical Report no. 25. In press. Successes, problems, and control of introduced mysid populations in lakes and reservoirs. N. Am. J. Fish. Manage.

Potter, D. S. 1978. The zooplankton of Flathead Lake: an historical review with suggestions for continuing lake resource management. Ph.D. dissertation, University of Montana, Missoula.

Richards, R. C., C. R. Goldman, T. C. Frantz, and R. Wickwire. 1975. Where have all the daphnia gone? The decline of a major cladoceran in Lake Tahoe, California-Nevada. Verhandlungen Internationale Vereinege Limnologie 19: 835-842.

Rieman, B. E., and B. Bowler. 1980. Kokanee trophic ecology and limnology in Pend Oreille Lake. Fisheries Bulletin no. 1. Idaho Department of Fish and Game, Boise.

Rieman, B. E., and C. M. Falter. 1981. Effects of the establishment of Mysis relicta on the macrozooplankton of a large lake. Trans. Am. Fish. Soc. 110: 613-620.

Roberts, L. 1990. Zebra mussel invasion threatens U.S. waters. Science 249: 1370-1372.

Schmidt, J. L., and D. L. Gilbert, eds. 1978. Big Game of North America: Ecology and Management. Stackpole Books, Harrisburg, PA.

Schoenherr, A. A. 1981. The role of competition in the replacement of native species by introduced species. Pages 173-203 in R. J. Naiman and D. L. Soltz, eds. Fishes in North American Deserts. John Wiley \& Sons, New York.

Schultz, J. W. 1919. Rising Wolf, the White Blackfoot. Houghton-Mifflin, Boston.

Shea, D. S. 1973. White-tailed deer eating salmon. Murrelet 54: 23.

Spencer, C. N., and D. L. King. 1984. Role of fish in regulation of plant and animal communities in lakes. Can J. Fish. Aquat. Sci. 41: 1851-1855.

Stalmaster, M. V., and J. A. Gessaman. 1984. Ecological energetics and foraging behavior of overwintering bald eagles. Ecol. Monogr. 54: 407-428.

Stanford, J. A., and B. K. Ellis. 1988. Pages 11-32 in Our Clean Water: Flathead's Resource of the Future. Flathead Basin Commission, Helena, MT.

Stanford, J. A., and J. V. Ward. 1986. Fish of the Colorado system. Pages 385-402 in B. Davies and K. Walker, eds. Ecology of River Systems. Dr. W. Junk Publ., The Hague, Netherlands.

Taylor, J. N., W. R. Courtenay, and J. A. McCann. 1984. Known impacts of exotic fish introductions in the continental United States. Pages 322-373 in W. R. Courtenay Jr. and J. R. Stouffer, eds. Distribution, Biology and Management of Exotic Fishes. Johns Hopkins University Press, Baltimore.

Vinyard, G. L., R. W. Drenner, and D. A. Hanzel. 1982. Feeding success of hatchery reared kokanee salmon when presented with zooplankton prey. Prog. Fish-Cult. 44: 37-39.

$\rightarrow$ Wells, L., and A. McLain. 1972. Lake Michigan: effects of exploitation, introductions, and eutrophication of the salmonid community. J. Fish. Res. Bd. Can. 29: 889-898.

Wydoski, R. S., and D. H. Bennett. 1981. Forage species in lakes and reservoirs of the western United States. Trans. Am. Fish. Soc. 110: 764-771.

Young, L. S. 1983. Movements of bald eagles associated with autumn concentrations in Glacier National Park, Montana. M.S. dissertation, University of Montana, Missoula. Young, L. S., B. R. McClelland, H. L. Allen, P. T. McClelland, and J. G. Crenshaw. 1983. Longrange movements of bald eagles associated with autumn concentrations in Glacier National Park, Montana: a preliminary report. Page 325 in D. M. Bird, ed. Biology and Management of Bald Eagles and Osprey. Harpell Press, Ste. Anne de Belluvue, Quebec. 